Prepared in cooperation with the U.S. Environmental Protection Agency

\title{
Water-Quality, Bed-Sediment, and Invertebrate Tissue Trace-Element Concentrations for Tributaries in the Clark Fork Basin, Montana, October 2017-September 2018
}

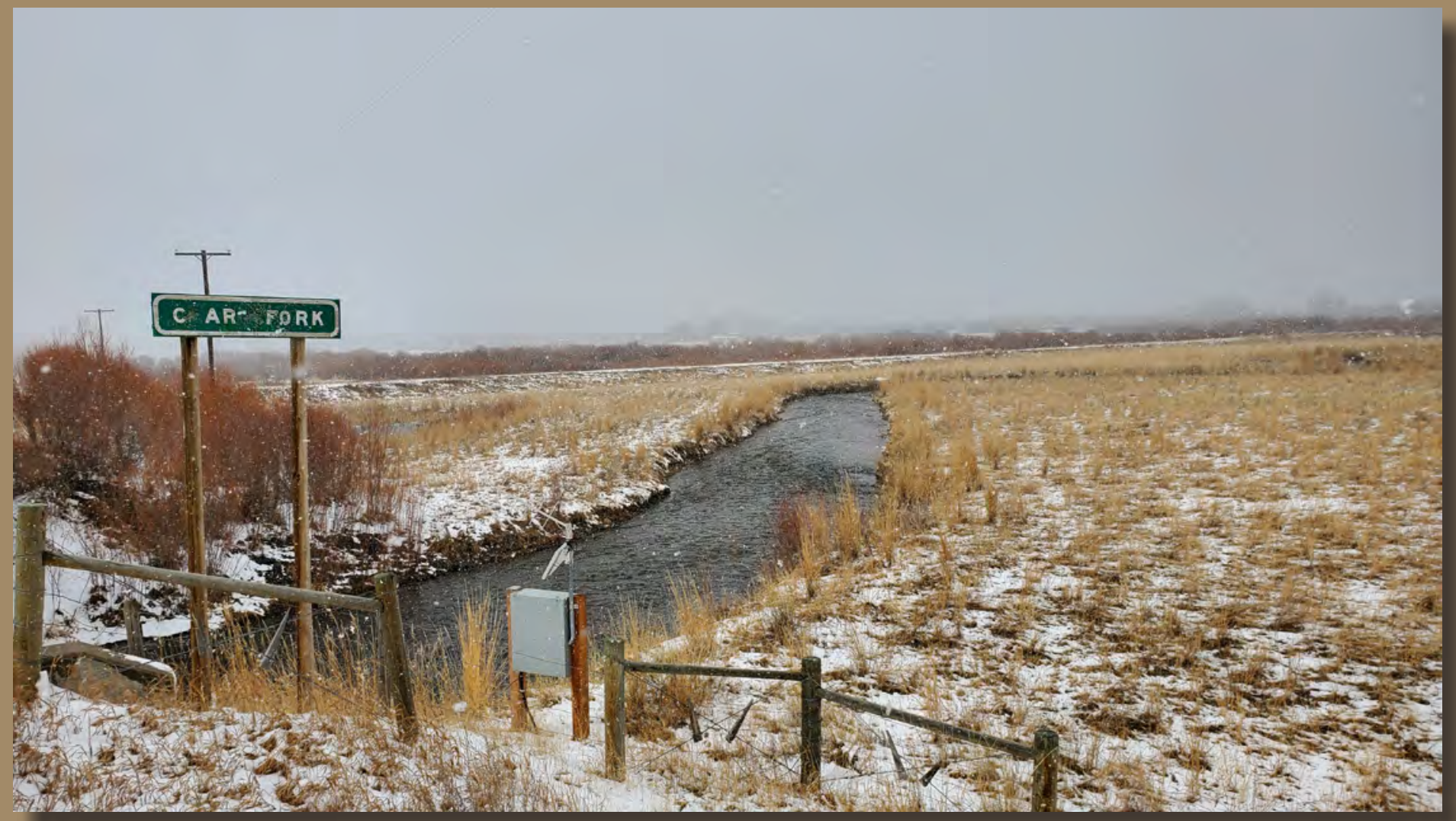

Open-File Report 2020-1067

U.S. Department of the Interior

U.S. Geological Survey 
Cover photo: Photograph showing Silver Bow Creek at Opportunity, taken from the Stewart Street bridge on March 3, 2020, in Opportunity, Montana, by Greg Clark, U.S. Geological Survey. 


\section{Water-Quality, Bed-Sediment, and Invertebrate Tissue Trace-Element Concentrations for Tributaries in the Clark Fork Basin, Montana, October 2017- September 2018}

By Gregory D. Clark, Michelle I. Hornberger, Thomas E. Cleasby, Terry L. Heinert, and Matthew A. Turner

Prepared in cooperation with the U.S. Environmental Protection Agency

Open-File Report 2020-1067 


\title{
U.S. Department of the Interior \\ DAVID BERNHARDT, Secretary
}

\author{
U.S. Geological Survey \\ James F. Reilly II, Director
}

U.S. Geological Survey, Reston, Virginia: 2020

For more information on the USGS - the Federal source for science about the Earth, its natural and living resources, natural hazards, and the environment-visit https://www.usgs.gov or call 1-888-ASK-USGS.

For an overview of USGS information products, including maps, imagery, and publications, visit https://store.usgs.gov/.

Any use of trade, firm, or product names is for descriptive purposes only and does not imply endorsement by the U.S. Government.

Although this information product, for the most part, is in the public domain, it also may contain copyrighted materials as noted in the text. Permission to reproduce copyrighted items must be secured from the copyright owner.

Suggested citation:

Clark, G.D., Hornberger, M.I., Cleasby, T.E., Heinert, T.L., and Turner, M.A., 2020, Water-quality, bed-sediment, and invertebrate tissue trace-element concentrations for tributaries in the Clark Fork Basin, Montana, October 2017September 2018: U.S. Geological Survey Open-File Report 2020-1067, 16 p., https://doi.org/10.3133/ofr20201067.

Associated data for this publication:

Boughton, G.K., Hornberger, M.I., Turner, M.A., and Clark, G.D., 2020, Water-quality, bed-sediment, and invertebrate tissue trace element concentrations for tributaries in the Clark Fork Basin, Montana, October 2017-September 2018 : U.S. Geological Survey data release, https://doi.org/10.5066/P98IRLJF.

U.S. Geological Survey, 2020, USGS water data for the Nation: U.S. Geological Survey National Water Information System database, https://doi.org/10.5066/F7P55KJN.

ISSN 2331-1258 (online) 


\section{Acknowledgments}

This report was prepared in cooperation with the U.S. Environmental Protection Agency. 



\section{Contents}

Acknowledgments ……...................................................................................................................

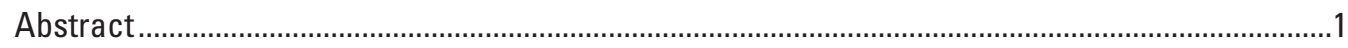

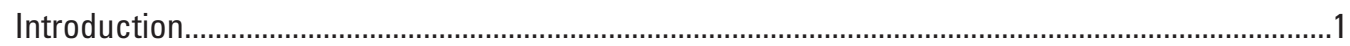

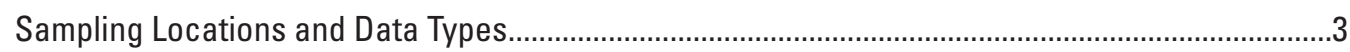

Trace-Element Concentrations and Physical Properties of Surface Water Samples........................7

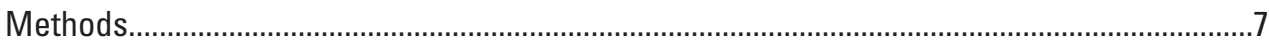

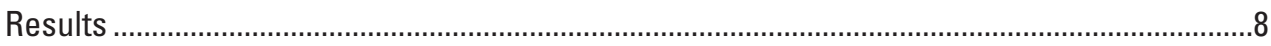

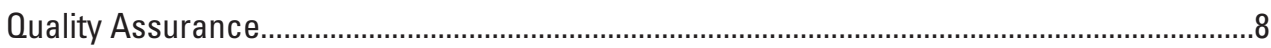

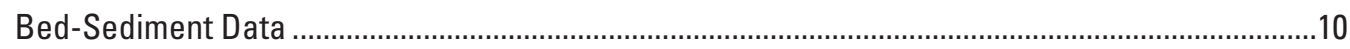

Methods

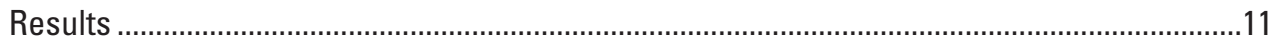

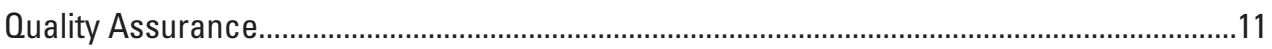

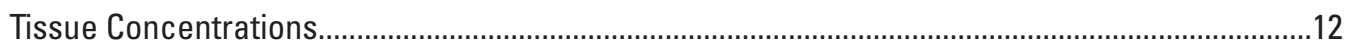

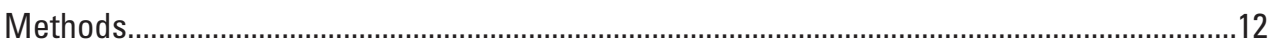

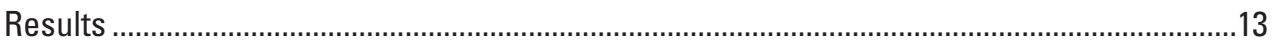

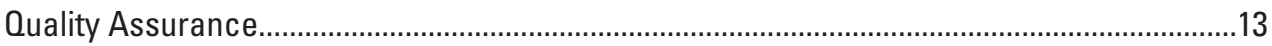

Statistical Summaries of Data .............................................................................................

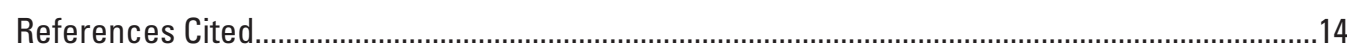

\section{Figures}

1. Map showing location of the study area in the Clark Fork Basin, Montana .....................2

\section{Tables}

1. Type and period of data collection at sampling sites in the Clark Fork

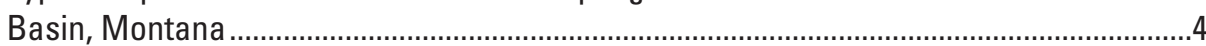

2. Properties and constituents measured onsite or analyzed in water, bed-sediment, and biota samples from the Clark Fork Basin, Montana .............................6

3. Data-quality objectives for analyses of water samples collected in the Clark Fork Basin, Montana

\section{Conversion Factors}

U.S. customary units to International System of Units

\begin{tabular}{ccc}
\hline Multiply & By & To obtain \\
\hline \multicolumn{3}{c}{ Length } \\
\hline mile $(\mathrm{mi})$ & 1.609 & kilometer $(\mathrm{km})$ \\
\hline \multicolumn{3}{c}{ Area } \\
\hline square mile $\left(\mathrm{mi}^{2}\right)$ & 2.590 & square kilometer $\left(\mathrm{km}^{2}\right)$ \\
\hline
\end{tabular}


Temperature in degrees Celsius $\left({ }^{\circ} \mathrm{C}\right)$ may be converted to degrees Fahrenheit $\left({ }^{\circ} \mathrm{F}\right)$ as follows:

$$
{ }^{\circ} \mathrm{F}=\left(1.8 \times^{\circ} \mathrm{C}\right)+32
$$

\section{Datum}

Horizontal coordinate information is referenced to the North American Datum of 1927 (NAD 27).

\section{Supplemental Information}

Concentrations of chemical constituents in water are given either in milligrams per liter ( $\mathrm{mg} / \mathrm{L}$ ) or micrograms per liter $(\mu \mathrm{g} / \mathrm{L})$.

Pore size is given in micrometers $(\mu \mathrm{m})$.

Suspended-sediment sizes are given in millimeters $(\mathrm{mm})$ and weights are given in grams $(\mathrm{g})$.

Bottle capacities or liquid measurements are given in milliliters $(\mathrm{mL})$.

Liquid-phase trace-element concentrations are given in micrograms per milliliter $(\mu \mathrm{g} / \mathrm{mL})$, and solid-phase concentrations are given in micrograms per gram $(\mu \mathrm{g} / \mathrm{g})$.

A water year is the 12-month period from 0ctober 1 through September 30 and is designated by the calendar year in which it ends. For example, water year 2018 is the period from October 1, 2017, through September 30, 2018.

\section{Abbreviations}

$\begin{array}{ll}\text { CRM } & \text { certified reference material } \\ \text { ESPD } & \text { Earth Systems Process Division } \\ \text { ICP-MS } & \text { inductively coupled plasma-mass spectrometry } \\ \text { LRL } & \text { laboratory reporting level } \\ \text { MRL } & \text { minimum reporting level } \\ \text { NIST } & \text { National Institute of Standards and Technology } \\ \text { NWIS } & \text { National Water Information System } \\ \text { NWQL } & \text { National Water Quality Laboratory } \\ \text { RSD } & \text { relative standard deviation } \\ \text { Spp. } & \text { species } \\ \text { SRM } & \text { standard reference material } \\ \text { USGS } & \text { U.S. Geological Survey }\end{array}$




\title{
Water-Quality, Bed-Sediment, and Invertebrate Tissue Trace-Element Concentrations for Tributaries in the Clark Fork Basin, Montana, October 2017-September 2018
}

\author{
By Gregory D. Clark, Michelle I. Hornberger, Thomas E. Cleasby, Terry L. Heinert, and Matthew A. Turner
}

\section{Abstract}

Water, bed sediment, and invertebrate tissue were sampled in streams from Butte to near Missoula, Montana, as part of a monitoring program in the Clark Fork Basin. The sampling program was completed by the U.S. Geological Survey, in cooperation with the U.S. Environmental Protection Agency, to characterize aquatic resources in the Clark Fork Basin and monitor trace elements associated with historical mining and smelting activities. Sampling sites were on the river and tributaries of the Clark Fork. Water samples were collected periodically at 20 sites from October 2017 through September 2018. Bed-sediment and tissue samples were collected once at 13 sites during August 2018.

Water-quality data included concentrations of major ions, dissolved organic carbon, nitrogen (nitrate plus nitrite), trace elements, and suspended sediment. Daily values of turbidity were determined at four sites. Bed-sediment data included trace-element concentrations in the fine-grained (less than 0.063 millimeter) fraction. Biological data included trace-element concentrations in whole-body tissue of aquatic benthic invertebrates. Statistical summaries of water-quality, bed-sediment, and invertebrate tissue trace element data for sites in the Clark Fork Basin were provided for the period of record: March 1985-September 2018.

\section{Introduction}

The Clark Fork originates near the town of Warm Springs in western Montana at the confluence of Silver Bow and Warm Springs Creeks (fig. 1). Along the 148-mile reach from Silver Bow Creek in Butte to the Clark Fork near Missoula, six major tributaries enter: Blacktail Creek, Warm Springs Creek, Little Blackfoot River, Flint Creek, Rock Creek, and Blackfoot River. Principal surface-water uses in the 6,000-square-mile Clark Fork Basin above Missoula include irrigation, stock watering, small-scale industry (Cannon and Johnson, 2004), and habitat for trout fisheries. Current (as of 2020) land uses are primarily cattle production, logging, mining, residential development, and recreation. Large-scale mining and smelting were prevalent in the basin for more than 100 years but are now either discontinued or reduced in scale.

Copper, gold, silver, and lead ores were extensively mined, milled, and smelted in the drainages of Silver Bow and Warm Springs Creeks from about the 1860s to the 1980s. Moderate- and small-scale mining also took place in the basins of most of the major tributaries to the upper Clark Fork. Tailings produced during past mineral processing commonly contained large quantities of trace elements such as arsenic, cadmium, copper, lead, and zinc. Eroded tailings mixed with stream sediment and deposited downstream in stream channels, on flood plains, in the Warm Springs Ponds, and at the former Milltown Reservoir (fig. 1; Andrews, 1987), whose dam (Milltown Dam, not shown) was breached on March 28, 2008.

Concern about the toxicity of trace elements to the aquatic ecosystem and human health has resulted in a comprehensive effort by State, Federal, Tribal, and private entities to characterize the aquatic resources in the Clark Fork Basin. This effort was designed to guide and monitor remedial activities and to evaluate the effectiveness of remediation and cleanup. Water-quality data have been collected by the U.S. Geological Survey (USGS) in the Clark Fork Basin since 1985 (Cleasby and others [2019] and references therein). Trace-element data for bed sediment and aquatic benthic invertebrates have been collected intermittently since 1986 as part of studies on the contamination of bed-sediment quality and bioaccumulation of metals led by the USGS Earth Systems Process Division (ESPD; Axtmann and Luoma, 1991; Cain and others, 1992, 1995; Axtmann and others, 1997; Hornberger and others, 1997). In March 1993, the efforts described previously, merged into a long-term (March 1985September 2018) monitoring program for water, bed sediment, and tissue in the basin and were implemented by the USGS, in cooperation with the U.S. Environmental Protection Agency, to systematically quantify the seasonal and annual variability in selected constituents. 

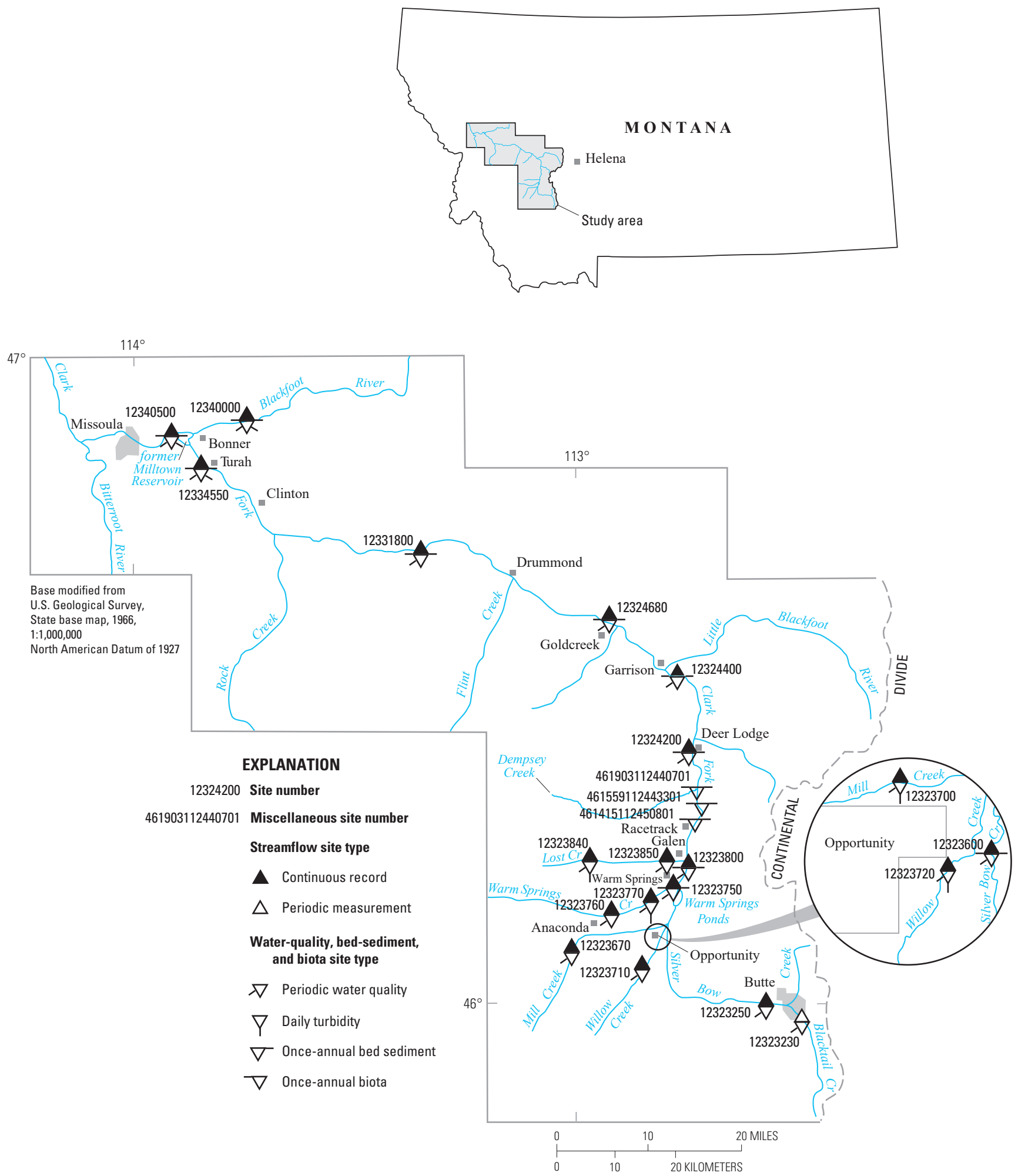

Figure 1. Location of the study area in the Clark Fork Basin, Montana. 
The purpose of the current report is to present water-quality data from samples collected at 20 sites and bed-sediment and biological data from samples collected at 13 sites in the Clark Fork Basin from October 2017 through September 2018 (fig. 1). Quality-assurance data are presented for water-quality, bed-sediment, and biota samples collected concurrently with primary data. Statistical summaries also are provided for all data collected for the period of record.

\section{Sampling Locations and Data Types}

Sampling sites for the monitoring program in the Clark Fork Basin from Butte to near Missoula (fig. 1) are on the Clark Fork main stem, including Silver Bow Creek; three major tributaries, Blacktail Creek, Warm Springs Creek, and Blackfoot River; and three smaller tributaries, Mill Creek, Willow Creek, and Lost Creek. The sites, types of data collected, and period of record for each data type are listed in table 1. Main-stem sampling sites were selected to divide the Clark Fork into reaches of approximate uniform length and to have each reach encompassing either a major tributary or depositional environment (that is, Warm Springs Ponds or the former Milltown Reservoir). Major tributaries were sampled to describe water-quality, bed-sediment, and biological characteristics of important hydrologic sources in the Clark Fork Basin and to provide reference comparisons to the main stem. The three smaller tributaries were sampled to gain better spatial resolution on sources of trace elements entering the Clark Fork in an area of historical metal-processing activities near Anaconda, Montana. Water-quality samples were collected at 20 sites, 6 to 8 times per year on a schedule designed to represent seasonal and hydrological variability. Daily turbidity values were computed using continuous turbidity monitors recording data every 15 minutes at four sites. Bed-sediment and invertebrate tissue samples were collected annually at 13 sites, and 1 additional site, Warm Springs Creek at Warm Springs (12323770), was sampled every 3 years. Continuous streamflow data measured every 15 minutes were collected at 19 sites.

Properties measured onsite and constituents for which water, bed-sediment, and biota samples were analyzed are listed in table 2. Data-quality objectives for analyses of water samples are listed in table 3. Results of onsite measurements of stream properties; laboratory analyses of water-quality, bed-sediment, and biota samples; and quality-assurance data for water year 2018 (October 1, 2017, through September 30, 2018) are available in a USGS data release (Boughton and others, 2020), along with statistical summaries of long-term water-quality, bed-sediment, and tissue data collected between March 1985 and September 2018.

Quality assurance of data was maintained using documented procedures described in the following sections. These quality-assurance data were designed to provide environmentally representative data. Acceptable results of the procedures were verified with quality-assurance samples that were collected systematically to provide a measure of the accuracy, precision, and bias of the environmental data and to identify variability associated with sampling, processing, or analysis. 
Table 1. Type and period of data collection at sampling sites in the Clark Fork Basin, Montana.

[--, no data; P, present; D, discontinued]

\begin{tabular}{|c|c|c|c|c|c|c|c|}
\hline Site number (fig. 1) & Site name & $\begin{array}{l}\text { Continuous- } \\
\text { record } \\
\text { streamflow }\end{array}$ & $\begin{array}{l}\text { 1Periodic water } \\
\text { quality }\end{array}$ & $\begin{array}{l}\text { Daily suspended } \\
\text { sediment }\end{array}$ & $\begin{array}{l}\text { Daily turbidity } \\
\text { (seasonal) }\end{array}$ & $\begin{array}{l}\text { 2Fine-grained bed } \\
\text { sediment }\end{array}$ & 1Tissue \\
\hline 12323230 & $\begin{array}{l}\text { Blacktail Creek at } \\
\text { Harrison Avenue, } \\
\text { at Butte }\end{array}$ & -- & $\begin{array}{l}\text { 03/1993-08/1995, } \\
\text { 12/1996-08/2003, } \\
\text { 12/2004-P }\end{array}$ & -- & -- & -- & -- \\
\hline 12323250 & $\begin{array}{c}\text { Silver Bow Creek } \\
\text { below Blacktail } \\
\text { Creek, at Butte }\end{array}$ & 10/1983-P & $\begin{array}{c}\text { 03/1993-08/1995 } \\
\text { 12/1996-P }\end{array}$ & -- & -- & -- & -- \\
\hline 12323600 & $\begin{array}{l}\text { Silver Bow Creek at } \\
\text { Opportunity }\end{array}$ & 07/1988-P & $\begin{array}{c}\text { 03/1993-08/1995 } \\
\text { 12/1996-P }\end{array}$ & 03/1993-09/1995, D & -- & 07/1992-P & $\begin{array}{l}\text { 07/1992, } \\
\text { 08/1994-08/1995, } \\
\text { 08/1997-P }\end{array}$ \\
\hline 12323670 & $\begin{array}{l}\text { Mill Creek near } \\
\text { Anaconda }\end{array}$ & 10/2004-P & $12 / 2004-\mathrm{P}$ & -- & 06/2006-09/2012, D & -- & -- \\
\hline 12323700 & $\begin{array}{l}\text { Mill Creek at } \\
\text { Opportunity }\end{array}$ & 04/2003-P & 03/2003-P & -- & 04/2013-P & -- & -- \\
\hline 12323710 & $\begin{array}{l}\text { Willow Creek near } \\
\text { Anaconda }\end{array}$ & 03/2005-P & 12/2004-P & -- & 06/2006-09/2012, D & -- & -- \\
\hline 12323720 & $\begin{array}{l}\text { Willow Creek at } \\
\text { Opportunity }\end{array}$ & 04/2003-P & 03/2003-P & -- & 04/2013-P & -- & -- \\
\hline 12323750 & $\begin{array}{l}\text { Silver Bow Creek at } \\
\text { Warm Springs }\end{array}$ & $\begin{array}{c}\text { 03/1972-09/1979, } \\
\text { 04/1993-P }\end{array}$ & 03/1993-P & 04/1993-09/1995, D & -- & 07/1992-P & 07/1992-P \\
\hline 12323760 & $\begin{array}{c}\text { Warm Springs Creek } \\
\text { near Anaconda }\end{array}$ & 10/1997-P & $10 / 2005-P$ & -- & 05/2006-09/2012, D & -- & -- \\
\hline 12323770 & $\begin{array}{c}\text { Warm Springs Creek } \\
\text { at Warm Springs }\end{array}$ & 10/1983-P & 03/1993-P & -- & 04/2013-P & $\begin{array}{l}\text { 08/1995, 08/1997, } \\
\text { 08/1999, 08/2002, } \\
08 / 2005,08 / 2008 \\
08 / 2011,08 / 2014 \\
08 / 2017\end{array}$ & $\begin{array}{l}\text { 08/1995, 08/1997, } \\
\text { 08/1999, 08/2002, } \\
08 / 2005,08 / 2008, \\
08 / 2011,08 / 2014, \\
08 / 2017\end{array}$ \\
\hline 12323800 & $\begin{array}{l}\text { Clark Fork near } \\
\text { Galen }\end{array}$ & 07/1988-P & 07/1988-P & -- & -- & 08/1987, 08/1991-P & 08/1987, 08/1991-P \\
\hline 12323840 & $\begin{array}{l}\text { Lost Creek near } \\
\text { Anaconda }\end{array}$ & 10/2004-P & $12 / 2004-\mathrm{P}$ & -- & 05/2006-P & -- & -- \\
\hline 12323850 & $\begin{array}{l}\text { Lost Creek near } \\
\text { Galen }\end{array}$ & 04/2003-P & 03/2003-P & -- & -- & -- & -- \\
\hline 461415112450801 & $\begin{array}{l}\text { Clark Fork below } \\
\text { Lost Creek, near } \\
\text { Galen }\end{array}$ & -- & -- & -- & -- & 08/1996-P & 08/1996-P \\
\hline
\end{tabular}


Table 1. Type and period of data collection at sampling sites in the Clark Fork Basin, Montana.-Continued

[--, no data; P, present; D, discontinued]

\begin{tabular}{|c|c|c|c|c|c|c|c|}
\hline Site number (fig. 1) & Site name & $\begin{array}{l}\text { Continuous- } \\
\text { record } \\
\text { streamflow }\end{array}$ & $\begin{array}{l}\text { Periodic water } \\
\text { quality }\end{array}$ & $\begin{array}{l}\text { Daily suspended } \\
\text { sediment }\end{array}$ & $\begin{array}{l}\text { Daily turbidity } \\
\text { (seasonal) }\end{array}$ & $\begin{array}{l}\text { 2Fine-grained bed } \\
\text { sediment }\end{array}$ & ${ }^{1}$ Tissue \\
\hline 461559112443301 & $\begin{array}{l}\text { Clark Fork at county } \\
\text { bridge, near } \\
\text { Racetrack }\end{array}$ & -- & -- & -- & -- & 08/1996-P & 08/1996-P \\
\hline 461903112440701 & $\begin{array}{l}\text { Clark Fork at } \\
\text { Dempsey Creek } \\
\text { diversion, near } \\
\text { Racetrack }\end{array}$ & -- & -- & -- & -- & 08/1996-P & 08/1996-P \\
\hline 12324200 & $\begin{array}{l}\text { Clark Fork at Deer } \\
\text { Lodge }\end{array}$ & 10/1978-P & 03/1985-P & $\begin{array}{c}\text { 03/1985-08/1986, } \\
\text { 04/1987-03/2003, } \\
\text { 08/2003-2014, D }\end{array}$ & 03/2016-09/2016, D & $\begin{array}{l}\text { 08/1986-08/1987, } \\
\text { 08/1990-P }\end{array}$ & $\begin{array}{l}\text { 08/1986-08/1987, } \\
\text { 08/1990-P }\end{array}$ \\
\hline 12324400 & $\begin{array}{l}\text { Clark Fork above } \\
\text { Little Blackfoot } \\
\text { River, near } \\
\text { Garrison }\end{array}$ & 02/2009-P & 03/2009-P & -- & -- & 08/2009-P & 08/2009-P \\
\hline 12324680 & $\begin{array}{c}\text { Clark Fork at } \\
\text { Goldcreek }\end{array}$ & 10/1977-P & 03/1993-P & -- & -- & 07/1992-P & 07/1992-P \\
\hline 12331800 & $\begin{array}{l}\text { Clark Fork near } \\
\text { Drummond }\end{array}$ & 04/1993-P & 03/1993-P & -- & -- & $\begin{array}{l}\text { 08/1986, 08/1987, } \\
\text { 08/1991-P }\end{array}$ & 08/1986, 08/1991-P \\
\hline 12334550 & $\begin{array}{l}\text { Clark Fork at Turah } \\
\text { Bridge, near } \\
\text { Bonner }\end{array}$ & 03/1985-P & 03/1985-P & $\begin{array}{l}\text { 03/1985-03/2003, } \\
\text { 08/2003-09/2016, } \\
\text { D }\end{array}$ & -- & 08/1986, 08/1991-P & 08/1986, 08/1991-P \\
\hline 12340000 & $\begin{array}{l}\text { Blackfoot River near } \\
\text { Bonner }\end{array}$ & 10/1939-P & 03/1985-P & $\begin{array}{l}\text { 07/1986-04/1987, } \\
\text { 06/1988-09/1995, } \\
\text { 10/2005-09/216, } \\
\text { D }\end{array}$ & -- & $\begin{array}{l}\text { 08/1986-08/1987, } \\
\text { 08/1991, } \\
\text { 08/1993-08/1996, } \\
\text { 08/1998-08/2001, } \\
\text { 09/2003, } \\
\text { 08/2006-P }\end{array}$ & $\begin{array}{c}\text { 08/1986-08/1987, } \\
\text { 08/1991, 08/1993, } \\
\text { 08/1996, 08/1998, } \\
\text { 09/2000, 09/2003, } \\
\text { 08/2006-P }\end{array}$ \\
\hline 12340500 & $\begin{array}{l}\text { Clark Fork above } \\
\text { Missoula }\end{array}$ & 03/1929-P & 307/1986-P & $\begin{array}{l}\text { 07/1986-04/1987, } \\
\text { 06/1988-01/1996, } \\
\text { 03/1996-03/2003, } \\
\text { 08/2003-09/216, } \\
\text { D }\end{array}$ & 04/2007-09/2007, D & 08/1997-P & 08/1997-P \\
\hline
\end{tabular}

${ }^{1}$ Onsite measurements of physical properties and laboratory analyses for selected major ions, trace elements, and suspended sediment. Before March 1993 , laboratory analyses included only trace elements and suspended sediment. In 2012, dissolved organic carbon and turbidity analyses were included at select sites. In 2013, nutrient sample analyses were included for two sites near Butte, Montana.

${ }^{2}$ Laboratory analyses of fine-grained bed sediment and aquatic benthic insects for trace elements.

3Before October 1989, water-quality data for Clark Fork above Missoula included only suspended-sediment data. 
Table 2. Properties and constituents measured onsite or analyzed in water, bed-sediment, and biota samples from the Clark Fork Basin, Montana.

\begin{tabular}{|c|c|c|c|}
\hline \multicolumn{2}{|c|}{ Water } & \multirow{2}{*}{$\begin{array}{c}\begin{array}{c}\text { Bed } \\
\text { sediment }\end{array} \\
\text { Constituent }\end{array}$} & \multirow{2}{*}{$\begin{array}{c}\text { Tissue } \\
\text { Constituent }\end{array}$} \\
\hline Property & Constituent & & \\
\hline Streamflow & $\begin{array}{l}\text { Hardness } \\
\quad \text { (calculated) }\end{array}$ & Arsenic & Arsenic \\
\hline $\mathrm{pH}$ & Calcium & Cadmium & Cadmium \\
\hline $\begin{array}{l}\text { Specific } \\
\text { conductance }\end{array}$ & Magnesium & Chromium & Chromium \\
\hline Temperature & Potassium & Copper & Copper \\
\hline \multirow[t]{16}{*}{ Turbidity } & Sodium & Iron & Iron \\
\hline & Alkalinity & Lead & Lead \\
\hline & Chloride & Manganese & Manganese \\
\hline & Fluoride & Nickel & Nickel \\
\hline & Silica & Zinc & Zinc \\
\hline & Sulfate & & \\
\hline & $\begin{array}{l}\text { Nitrate plus } \\
\text { nitrite }\end{array}$ & & \\
\hline & Cadmium & & \\
\hline & Copper & & \\
\hline & Iron & & \\
\hline & Lead & & \\
\hline & Manganese & & \\
\hline & Zinc & & \\
\hline & Arsenic & & \\
\hline & $\begin{array}{c}\text { Dissolved } \\
\text { organic } \\
\text { carbon }\end{array}$ & & \\
\hline & $\begin{array}{l}\text { Suspended } \\
\text { sediment }\end{array}$ & & \\
\hline
\end{tabular}

Table 3. Data-quality objectives for analyses of water samples collected in the Clark Fork Basin, Montana.

[lab, laboratory; NTRU, nephelometric turbidity ratio unit; --, not determined; $\mathrm{mg} / \mathrm{L}$, milligram per liter; $\mu \mathrm{g} / \mathrm{L}$, microgram per liter; $\mathrm{mm}$, millimeter]

\begin{tabular}{|c|c|c|c|}
\hline \multirow[b]{3}{*}{ Constituent } & \multicolumn{3}{|c|}{ Data-quality objectives } \\
\hline & Detectability & Precision & Bias \\
\hline & $\begin{array}{l}\text { Laboratory } \\
\text { reporting } \\
\text { level }\end{array}$ & $\begin{array}{l}\text { Maximum } \\
\text { relative } \\
\text { standard } \\
\text { deviation } \\
\text { of replicate } \\
\text { analyses } \\
\text { (percent) }\end{array}$ & $\begin{array}{c}\text { Maximum } \\
\text { deviation } \\
\text { of spike } \\
\text { recovery } \\
\text { (percent) }\end{array}$ \\
\hline $\begin{array}{l}\text { Turbidity, unfiltered, lab, } \\
\text { NTRU }\end{array}$ & 2.0 units & 20 & -- \\
\hline Calcium, filtered & $0.022 \mathrm{mg} / \mathrm{L}$ & 20 & -- \\
\hline Magnesium, filtered & $0.01 \mathrm{mg} / \mathrm{L}$ & 20 & -- \\
\hline Potassium, filtered & $0.3 \mathrm{mg} / \mathrm{L}$ & 20 & -- \\
\hline Sodium, filtered & $0.4 \mathrm{mg} / \mathrm{L}$ & 20 & -- \\
\hline Alkalinity, filtered, lab & $4.0 \mathrm{mg} / \mathrm{L}$ & 20 & -- \\
\hline Chloride, filtered & $0.02 \mathrm{mg} / \mathrm{L}$ & 20 & -- \\
\hline Fluoride, filtered & $0.01 \mathrm{mg} / \mathrm{L}$ & 20 & -- \\
\hline Silica, filtered & $0.05 \mathrm{mg} / \mathrm{L}$ & 20 & -- \\
\hline Sulfate, filtered & $0.02 \mathrm{mg} / \mathrm{L}$ & 20 & -- \\
\hline $\begin{array}{l}\text { Nitrate plus nitrite, } \\
\text { filtered }\end{array}$ & $0.01 \mathrm{mg} / \mathrm{L}$ & 20 & -- \\
\hline Cadmium, filtered & $0.03 \mu \mathrm{g} / \mathrm{L}$ & 20 & 25 \\
\hline $\begin{array}{l}\text { Cadmium, unfiltered } \\
\text { recoverable }\end{array}$ & $0.03 \mu \mathrm{g} / \mathrm{L}$ & 20 & 25 \\
\hline Copper, filtered & $0.4 \mu \mathrm{g} / \mathrm{L}$ & 20 & 25 \\
\hline $\begin{array}{l}\text { Copper, unfiltered } \\
\text { recoverable }\end{array}$ & $0.4 \mu \mathrm{g} / \mathrm{L}$ & 20 & 25 \\
\hline Iron, filtered & $10 \mu \mathrm{g} / \mathrm{L}$ & 20 & 25 \\
\hline $\begin{array}{l}\text { Iron, unfiltered } \\
\text { recoverable }\end{array}$ & $5 \mu \mathrm{g} / \mathrm{L}$ & 20 & 25 \\
\hline Lead, filtered & $0.02 \mu \mathrm{g} / \mathrm{L}$ & 20 & 25 \\
\hline $\begin{array}{l}\text { Lead, unfiltered } \\
\text { recoverable }\end{array}$ & $0.06 \mu \mathrm{g} / \mathrm{L}$ & 20 & 25 \\
\hline Manganese, filtered & $0.4 \mu \mathrm{g} / \mathrm{L}$ & 20 & 25 \\
\hline $\begin{array}{l}\text { Manganese, unfiltered } \\
\text { recoverable }\end{array}$ & $0.4 \mu \mathrm{g} / \mathrm{L}$ & 20 & 25 \\
\hline Zinc, filtered & $2 \mu \mathrm{g} / \mathrm{L}$ & 20 & 25 \\
\hline $\begin{array}{l}\text { Zinc, unfiltered } \\
\text { recoverable }\end{array}$ & $2 \mu \mathrm{g} / \mathrm{L}$ & 20 & 25 \\
\hline Arsenic, filtered & $0.1 \mu \mathrm{g} / \mathrm{L}$ & 20 & 25 \\
\hline $\begin{array}{l}\text { Arsenic, unfiltered } \\
\text { recoverable }\end{array}$ & $0.1 \mu \mathrm{g} / \mathrm{L}$ & 20 & 25 \\
\hline Organic carbon, filtered & $0.23 \mathrm{mg} / \mathrm{L}$ & 20 & -- \\
\hline $\begin{array}{l}\text { Sediment, suspended, } \\
\text { percent finer than } \\
0.062 \mathrm{~mm}\end{array}$ & 1 percent & 20 & -- \\
\hline Sediment, suspended & $1 \mathrm{mg} / \mathrm{L}$ & 20 & -- \\
\hline
\end{tabular}




\section{Trace-Element Concentrations and Physical Properties of Surface Water Samples}

Water-quality data consist of onsite stream properties and laboratory determination of concentrations of chemical and physical constituents (listed in table 2) in stream samples. Water samples were collected at 20 sites in the Clark Fork Basin 6 to 8 times per year on a schedule designed to describe seasonal and hydrologic variability. Turbidity monitors were operated seasonally (March to September 2018) at four sites; continuous turbidity data (recorded every 15 minutes) were used to compute daily mean turbidity values (table 1). Water-quality data are available through the USGS National Water Information System (NWIS) database at https://waterdata.usgs.gov/nwis/qw (U.S. Geological Survey, 2020).

\section{Methods}

Water samples were collected and composited from vertical transits throughout the stream depth at multiple locations along the channel cross section using depth- and width-integration methods described by Ward and Harr (1990), Edwards and Glysson (1999), and the U.S. Geological Survey (variously dated). These methods provided vertically and laterally discharge-weighted composite samples that represented the flow passing through the cross section of the stream. Samples were collected with isokinetic depth-integrating water-quality samplers (Davis and the Federal Interagency Sedimentation Project, 2005) constructed of plastic or coated with a nonmetallic rubber-coating paint and equipped with polytetrafluoroethylene nozzles.

Instantaneous streamflow was determined at the time of water sampling either by direct measurement or from stage-discharge rating tables (Rantz and others, 1982). Daily mean streamflow values during ice periods were labeled as estimated because backwater affected the stage-discharge relation. Onsite measurements of $\mathrm{pH}$, specific conductance, and water temperature were measured during water sample collection. Sample filtration and preservation was completed according to procedures described by Ward and Harr (1990), Horowitz and others (1994), and the U.S. Geological Survey (variously dated).

Concentrations of arsenic, cadmium, copper, lead, manganese, and zinc in filtered samples $(0.45$-micrometer $[\mu \mathrm{m}]$ pore size) were measured using inductively coupled plasma-mass spectrometry (ICP-MS; Garbarino and others, 2006). Concentrations of calcium, magnesium, and iron in filtered samples were measured using inductively coupled plasma-atomic emission spectrometry (Fishman and Friedman, 1989). Calcium and magnesium concentrations were used to calculate water hardness. Concentrations of potassium, sodium, alkalinity, chloride, fluoride, silica, sulfate, nitrogen (nitrate plus nitrite), and dissolved organic carbon were measured in filtered samples collected at select sites in the upper Clark Fork Basin. Potassium was measured by Standard Method 3120 (American Public Health Association, 1998); sodium and silica were analyzed by inductively coupled plasma-atomic emission spectrometry (Fishman, 1993); alkalinity was measured by electrometric titration (Fishman and Friedman, 1989); chloride, fluoride, and sulfate were measured by ion chromatography (Fishman and Friedman, 1989); nitrogen (nitrate plus nitrite) was measured by colorimetric enzymatic reduction (Patton and Kryskalla, 2011); and dissolved organic carbon was measured by persulfate oxidation and infrared spectrometry (Brenton and Arnett, 1993). Recoverable concentrations of trace elements were measured in unfiltered samples that were first digested with dilute hydrochloric acid (Hoffman and others, 1996). For cadmium, iron, lead, and manganese, the digested samples were analyzed by ICP-MS as described by Garbarino and Struzeski (1998). For arsenic, copper, and zinc, the digested samples were analyzed by ICP-MS as described by Garbarino and others (2006). Turbidity was measured using Standard Method 2130 (American Public Health Association, 1998) in selected unfiltered samples. All samples were analyzed at the USGS National Water Quality Laboratory (NWQL) in Denver, Colorado.

Water samples for analysis of suspended sediment were collected from multiple vertical transits when periodic water samples were collected. Water samples were analyzed for suspended-sediment concentration and the percentage of suspended-sediment mass finer than 0.062 -millimeter $(\mathrm{mm})$ diameter (silt size and smaller) by the USGS Wyoming-Montana Water Science Center Sediment Laboratory (hereinafter referred to as the "Wyoming-Montana Sediment Laboratory") in Helena, Mont., according to methods described by Guy (1969) and Dodge and Lambing (2006).

Continuous turbidity was measured from early spring (after ice breakup) to early fall (before stream freezeup) using model 6136 turbidity sensors (Yellow Springs Instruments, Yellow Springs, Ohio) at four tributary sites in the upper Clark Fork Basin near Anaconda (table 1). Turbidity values were recorded every 15 minutes and are stored in the USGS NWIS database (U.S. Geological Survey, 2020) at https://waterdata.usgs.gov/mt/nwis/current?type=quality. The in situ values differ from the results of laboratory-measured turbidity in discrete water-quality samples because of differences in the instrumentation and sampling procedures. Continuous recordings enable determination of the minimum and maximum turbidity values for each day and a daily mean turbidity, which is based on the average of all values in a 24-hour period. Procedures for the operation of continuous turbidity monitors and for daily record computations are described by Wagner and others (2006). 


\section{Results}

Water-quality data from samples collected periodically during water year 2018 (October 1, 2017, through September 30,2018) are listed in the accompanying data release (Boughton and others, 2020). In water year 2018, there was one water-quality sample at Willow Creek near Anaconda (12323710) on March 26, 2018, with missing values because of site inaccessibility caused by excessive snow. Daily maximum, minimum, and mean turbidity at four sites are listed in the accompanying data release along with monthly summary statistics (Boughton and others, 2020). Water-quality data are available in the USGS NWIS database (U.S. Geological Survey, 2020).

\section{Quality Assurance}

Quality-assurance procedures used for the collection and field processing of water samples are described by Ward and Harr (1990), Horowitz and others (1994), Edwards and Glysson (1999), Lambing (2006), and the U.S. Geological Survey (variously dated). Standard procedures used by the NWQL for internal sample handling and quality assurance are described by Friedman and Erdmann (1982), Jones (1987), and Pritt and Raese (1995). Quality-assurance procedures used by the Wyoming-Montana Sediment Laboratory are described by Dodge and Lambing (2006). Standard procedures used for the calibration, measurement, and quality assurance of turbidity monitors are described by Anderson (2005).

The quality of analytical results reported for water samples was evaluated using quality-control samples that were sampled and analyzed concurrently with primary environmental samples. These quality-control samples consisted of replicates, spikes, and blanks that provided quantitative information on the precision and bias of the overall field and laboratory processes. The number of quality-control samples represented about 15 percent of the total number of water samples.

Replicate data provided an assessment of the precision (reproducibility) of analytical results and collection variability (U.S. Geological Survey, variously dated). Replicate samples were collected in the field (field replicate) either by repeating the collection process (sequential or concurrent replicate) to obtain two or more independent composite samples or by splitting a single composite sample into two or more subsamples (split replicate). The individual replicate samples were analyzed separately. Likewise, a single sample can be analyzed two or more times in the laboratory to obtain a measure of analytical precision (laboratory replicate).

Precision of analytical results for field replicates can be affected by numerous sources of variability within the field and laboratory environments, including sample collection, processing, and analysis. Overall precision for samples exposed to field and laboratory sources of variability were provided by obtaining replicate stream samples for chemical analysis by splitting a composite stream sample. Replicate stream samples for suspended-sediment analysis were obtained in the field by collecting two independent cross-sectional samples. Analyses of field replicate samples indicated the reproducibility of environmental data that were affected by the combined potential variability introduced by field and laboratory processes.

In addition to analyzing quality-control samples submitted from the field, internal quality-assurance practices are completed systematically by the NWQL to provide quality control of analytical procedures (D.L. Stevenson, U.S. Geological Survey, written commun., 2012). These internal practices include analyses of quality-control samples such as calibration standard samples, standard reference water samples, replicate samples, deionized-water blank samples, or spiked samples at a proportion equivalent to at least 10 percent of the samples loaded. The NWQL participates in a blind-sample program in which standard reference water samples prepared by the USGS, Water Mission Area, Laboratory and Analytical Services Division, Quality Systems Branch (QSB) are routinely inserted into the sample line for each analytical method at a frequency proportional to the sample load. The laboratory also participates in external evaluation studies and audits with the National Environmental Laboratory Accreditation Program, the U.S. Environmental Protection Agency, Environment Canada, and the USGS Quality Systems Branch to assess analytical performance.

Precision of analytical results for laboratory replicates, which exclude field sources of variability, was determined using two independent chemical analyses of aliquots from a single sample selected from the group of samples constituting each analytical run. A separate analysis of the sample was made at the beginning and end of each analytical run to provide information on the reproducibility of laboratory analytical results independent of variability caused by field sample collection and processing. Laboratory replicates of suspended-sediment samples were not obtainable because the samples were consumed during the analysis.

Spiked samples were used to evaluate bias, which measures the ability of an analytical method to accurately quantify a known amount of analyte added to a sample. In the laboratory, deionized-water blank samples and aliquots of stream samples were spiked with known amounts of the same trace elements for which water samples were being analyzed. Analyses of spiked blanks indicated if the spiking procedure and analytical method are within control for water that is presumably free of chemical interferences. Analyses of spiked aliquots of stream samples indicated if the chemical matrix of the stream water interferes with the analytical measurement and if these interferences could contribute substantial bias to reported trace-element concentrations for stream samples. 
Field blank samples were submitted for every field trip and analyzed to identify the presence and magnitude of contamination that could bias analytical results. Field blanks consisted of deionized water that is certified as constituent free and is processed in the field through clean sampling equipment used to collect stream samples. These blanks were subjected to the same processing (sample splitting, filtration, preservation, transportation, and laboratory handling) as stream samples. Blank samples were analyzed for the same constituents as stream samples to detect contamination.

All water samples were handled in accordance with chain-of-custody procedures that provide documentation of sample identity, shipment, receipt, and laboratory handling (Driscoll and Hatcher, 2010). All environmental and quality-control samples submitted from a sampling episode were stored in a secure area of the NWQL and analyzed as a discrete sample group, independent of other samples submitted to the NWQL; therefore, the quality-control data apply solely to the analytical results for stream samples reported herein and provide a direct measure of data quality for this study.

Data-quality objectives (table 3) were established by the USGS and U.S. Environmental Protection Agency as part of the study plan for the expanded long-term monitoring program started in 1993. The objectives identify the analytical requirements of detectability and serve as a guide for identifying questionable data by establishing acceptable limits for precision and bias of laboratory results. Comparisons of quality-control data to data-quality objectives were used to evaluate if sampling and analytical procedures produced environmentally representative data in a consistent manner. Data that did not meet the objectives were evaluated for acceptability; if necessary, additional quality-control samples were submitted and corrective action was taken.

The precision of analytical results was determined by calculating the standard deviation of the differences in concentrations between replicate analyses. These replicate analyses consisted of pairs of field replicate samples and laboratory replicates. Standard deviations were calculated according to the following equation (Taylor, 1987):

$$
S=\sqrt{\frac{\sum d^{2}}{2 k}}
$$

where

$S \quad$ is the standard deviation of the difference in concentration between replicate analyses,

$d \quad$ is the difference in concentration between each pair of replicate analyses, and

$k \quad$ is the number of pairs of replicate analyses.

Precision also was expressed as a relative standard deviation (RSD), in percent, which was computed from the standard deviation and the mean concentration for all the replicate analyses. Expressing precision relative to a mean concentration standardized the comparison of precision among individual constituents. The RSD was calculated according to the following equation (Taylor, 1987):

$$
R S D=\frac{S}{\bar{x}} \times 100
$$

where

$$
\begin{aligned}
& R S D \text { is the relative standard deviation, } \\
& \frac{S}{x} \text { is the standard deviation, and } \\
& \text { is the mean concentration for all replicate } \\
& \text { analyses. }
\end{aligned}
$$

Sample results and the corresponding field replicate data are listed in the accompanying data release (Boughton and others, 2020). The precision for each constituent estimated from field replicate analyses and the precision for each constituent estimated from laboratory replicate analyses are listed in the accompanying data release (Boughton and others, 2020). Statistics summarizing the precision of analytical results for field and laboratory replicates were calculated using unrounded values stored in laboratory data files. Precision estimates for field and laboratory replicates were within the acceptable 20-percent RSD limit for all constituents (Boughton and others, 2020), so no adjustments were made to analytical data based on replicate analyses precision.

Recovery efficiencies for analyses of constituents were determined by comparing a sample and a spiked aliquot of the same sample. The data-quality objective for acceptable spike recoveries of trace elements in water samples was a maximum deviation of 25 percent from a theoretical 100-percent recovery of an added constituent (table 3). At NWQL, a spiked deionized-water blank sample and a spiked aliquot of a stream sample were prepared and analyzed along with the original unspiked sample. The differences between the spiked and unspiked sample concentrations were determined and used to compute recovery, in percent, according to equation 3 :

$$
R=\frac{D}{C} \times 100
$$

where

$$
\begin{aligned}
& R \quad \text { is the spike recovery, in percent; } \\
& D \quad \text { is the difference between the spiked and } \\
& \text { unspiked sample concentrations; and } \\
& C \quad \text { is the concentration of material used to spike } \\
& \text { the sample. }
\end{aligned}
$$

If the spike recovery of a trace element was outside a range of 75 to 125 percent, the instrument was recalibrated and the sample set and all spiked samples were reanalyzed for that element until recoveries were improved to the extent possible. Recovery efficiency for individual trace elements in spiked blank samples and in spiked stream samples is listed in the accompanying data release (Boughton and others, 2020). The mean recovery for spiked blank samples ranged from 97.0 to 107 percent (Boughton and others, 2020). 
The smallest individual constituent recovery was arsenic, filtered, at 90.2 percent, and the largest was manganese, filtered, at 112 percent. The 95-percent confidence intervals (Taylor, 1987) for the mean recovery for each constituent for which spiked blank samples were analyzed (Boughton and others, 2020) did not exceed a 25-percent deviation from an expected 100-percent recovery. The mean recovery for spiked stream samples (Boughton and others, 2020) ranged from 70.8 to 108 percent. The smallest constituent recovery was iron, unfiltered recoverable, at 34.9 percent, and the largest was arsenic, unfiltered recoverable, at 146 percent. The 95-percent confidence intervals for the mean spike recovery for each constituent for which stream water samples were analyzed (Boughton and others, 2020) did not exceed a 25 -percent deviation from an expected 100-percent recovery except for iron, unfiltered recoverable (41.8 percent), and arsenic, unfiltered recoverable (63.6 and 144 percent). No adjustments were made to analytical data based on the mean spike recovery.

High or low bias is indicated if the 95-percent confidence interval does not include 100-percent recovery, thereby indicating a consistent deviation or bias, either high or low. Confidence intervals for percentage recovery include 100 percent for all laboratory-spiked blank samples (Boughton and others, 2020) except for cadmium, unfiltered recoverable (102-113 percent); copper, unfiltered recoverable (101-108 percent); lead, filtered (103-106 percent); and lead, unfiltered recoverable (105-110 percent). Confidence intervals for percent recovery include 100 percent for all laboratory-spiked stream samples (Boughton and others, 2020) except for iron, unfiltered recoverable (41.8-99.9 percent). No adjustments were made to analytical results for stream samples based on spike recoveries.

Analytical results for field blanks are listed in the accompanying data release (Boughton and others, 2020). Field blanks with constituent concentrations less than or equal to the laboratory reporting level (LRL) indicated that the process of sample collection, field processing, and laboratory analysis is presumably free of contamination. If detectable concentrations of trace elements in field blanks were greater than or equal to twice the LRL, the concentrations were noted during data review. Analytical results from the field blank were evaluated for evidence of a consistent trend that could indicate systematic contamination. Sporadic, infrequent, nonconsecutive exceedances of twice the LRL most likely represented random contamination or laboratory-instrument calibration error that was not persistent in the process and was not likely to cause positive bias in a long-term record of analytical results; however, if concentrations for a particular constituent exceeded twice the LRL in field blanks from two consecutive field trips, additional blank samples were collected and submitted for analysis to identify the source of contamination.
Constituent concentrations in field blanks (Boughton and others, 2020) almost always were less than the LRL. One sample concentration of copper, filtered ( 0.43 microgram per liter $[\mu \mathrm{g} / \mathrm{L}])$, exceeded the LRL of $0.40 \mu \mathrm{g} / \mathrm{L}$. One sample concentration of copper, unfiltered recoverable $(0.9 \mu \mathrm{g} / \mathrm{L})$, exceeded the LRL of $0.4 \mu \mathrm{g} / \mathrm{L}$. One sample concentration of lead, unfiltered recoverable (E0.07 $\mu \mathrm{g} / \mathrm{L})$, exceeded the LRL of $0.06 \mu \mathrm{g} / \mathrm{L}$. One sample of organic carbon, filtered $(0.24 \mathrm{mg} / \mathrm{L})$, exceeded the LRL of $0.23 \mathrm{mg} / \mathrm{L}$. No adjustments were made to water-quality sample data based on a review of these results.

\section{Bed-Sediment Data}

Bed-sediment data for the long-term monitoring program in the Clark Fork Basin consisted of trace-element concentrations in the fine-grained (less than $0.063 \mathrm{~mm}$ ) fraction of bed-sediment samples. Bed-sediment samples were collected once annually at 13 sites (fig. 1; table 1) during low, stable flow conditions at about the same time of year as previous samples (typically in August) to facilitate data comparisons among years. The 2018 bed-sediment data are available in a machine-readable USGS data release (Boughton and others, 2020). For prior years, bed-sediment data can be obtained in a Microsoft Excel format from the authors. Warm Springs Creek at Warm Springs was sampled once every 3 years and was not sampled during water year 2018. Warm Springs Creek at Warm Springs was last sampled during water year 2017.

\section{Methods}

Fine-grained bed-sediment samples were collected in August 2018 using protocols described by Axtmann and Luoma (1991). Samples were collected from the surfaces of streambed deposits in areas near the edge of the stream using an acid-washed polypropylene scoop. Whenever possible, samples were collected from both sides of the stream.

Individual samples of bed sediment were collected by scooping material from the surfaces of three to five randomly selected deposits along pools or low-velocity areas. The three to five individual samples were combined to form a single composite sample. This collection process was repeated three times to obtain three composite samples. Each composite sample was wet sieved onsite through a $0.063-\mathrm{mm}$ polyester-mesh sieve using ambient stream water. The fraction of bed sediment in each composite sample that was finer than $0.063 \mathrm{~mm}$ was collected in an acid-washed 500-milliliter $(\mathrm{mL})$ polyethylene bottle and transported to the laboratory on ice. 
Bed-sediment samples were processed and analyzed at the USGS ESPD Ecology and Contaminants Project Laboratory in Menlo Park, California. Bed-sediment samples were oven dried at 60 degrees Celsius $\left({ }^{\circ} \mathrm{C}\right)$ and ground into smaller particle sizes using an acid-washed, ceramic mortar and pestle. Single aliquots of about $0.5-0.6$ gram of sediment from each of the three composite bed-sediment samples were digested using a hot, concentrated nitric acid reflux according to methods described by Luoma and Bryan (1981). Laboratory replicates were analyzed by taking an aliquot from one of the three sieved replicate samples at each site. After a 2-week digestion period, the aliquots were evaporated to dryness on a hot plate. The dry residue was reconstituted in $10 \mathrm{~mL}$ of $0.6 \mathrm{~N}$ (normal) hydrochloric acid. The reconstituted aliquots were then filtered through a $0.45-\mu \mathrm{m}$ pore-size filter using a syringe and an in-line disposable filter cartridge. The filtrate was diluted to a 1 to 10 ratio with $0.6 \mathrm{~N}$ hydrochloric acid. These final solutions were analyzed for arsenic, cadmium, chromium, copper, iron, lead, manganese, nickel, and zinc using inductively coupled plasma-optical emission spectrometry (Hornberger and others, 1997). The smallest concentration of a constituent that can be reliably reported for analyses of bed sediment is termed the minimum reporting level (MRL).

\section{Results}

Solid-phase concentrations of trace elements measured in samples of fine-grained bed sediment collected during August 2018 are listed in the accompanying data release (Boughton and others, 2020). Liquid-phase concentrations, measured in micrograms per milliliter, were analyzed in the reconstituted aliquots of digested bed sediment. Solid-phase concentrations, measured in micrograms per gram, were calculated using the following equation:

$$
\mu \mathrm{g} / \mathrm{g}=\frac{(\mu \mathrm{g} / \mathrm{mL})(\text { volume of digested sample, in } \mathrm{mL})(\text { dilution ratio })}{(\text { dry weight of sample, in grams })}
$$

where

$$
\begin{array}{cl}
\mu \mathrm{g} / \mathrm{g} & \begin{array}{c}
\text { is micrograms of trace element per gram of } \\
\text { sediment, by dry weight; }
\end{array} \\
\mu \mathrm{g} / \mathrm{mL} & \begin{array}{c}
\text { is micrograms per milliliter of liquid-phase } \\
\text { trace element; and }
\end{array} \\
\mathrm{mL} & \text { is milliliters. }
\end{array}
$$

The reported solid-phase concentrations (Boughton and others, 2020) are the means of all analyses for replicate aliquots from each composite bed-sediment sample collected at each site. Because the conversion from liquid-phase to solid-phase concentration is dependent on the dilution ratio and the dry weight of the sample, MRLs for some trace elements might differ among sites and among years.

\section{Quality Assurance}

The USGS protocols for field collection and processing of bed-sediment samples are designed to prevent contamination from metal sources. Nonmetallic sampling and processing equipment (white plastic scoop, funnel-frame apparatus, and 500-mL sample bottles) was acid washed and rinsed with deionized water before the collection of the first sample. Polyester-mesh sieves were washed in laboratory-grade detergent and rinsed with deionized water. All equipment received a field rinse onsite with native water. Sampling equipment used at more than one site was field rinsed thoroughly between sites with site-specific stream water. Separate sieves were used at each site and, therefore, did not require decontamination between sites. Bed-sediment samples were collected sequentially at sites along a generally increasing concentration gradient (that is, downstream sites have lower concentrations of contaminated bed sediments compared to upstream sites) to minimize effects from potential site-to-site carryover contamination (Axtmann and Luoma, 1991).

Quality assurance of analytical results for bed-sediment samples included laboratory-instrument calibration with standard solutions and analysis of quality-control samples designed to identify the presence and magnitude of bias (Ellen V. Axtmann, U.S. Geological Survey, written commun., 1994). Quality-control samples consisted of standard reference materials (SRMs) issued by the National Institute of Standards and Technology (NIST) and procedural blanks. In total, 10 low-concentration SRMs, 10 high-concentration SRMs, and 13 procedural blanks were analyzed.

SRMs are commercially prepared materials that have certified concentrations of trace elements. Analyses of SRMs were used to indicate the ability of the method to accurately measure a known quantity of a constituent. Multiple analyses of SRMs were made to derive a mean and 95-percent confidence interval for recovery. Recovery efficiency for trace-element analyses of SRMs for bed sediment is listed in the accompanying data release (Boughton and others, 2020). Two SRMs, consisting of agricultural soils and representing low and high concentrations of trace elements, were analyzed to test recovery efficiency for a range of concentrations like those discovered in the bed sediment in streams in the upper Clark Fork Basin.

The digestion process used to analyze bed-sediment samples was not a "total" digestion (does not liberate elements associated with crystalline lattices); therefore, 100 -percent recovery may not be achieved for elements strongly bound to the sediment. The percentage recovery of trace elements for SRM analyses that used less than a total digestion was useful to indicate which trace elements indicated strong sediment-binding characteristics in the SRM and if analytical recovery is consistent among multiple sets of analyses. 
Although data-quality objectives are not established for bed sediment, percentage recoveries for individual trace elements (Boughton and others, 2020) illustrated analytical performance. Metal recoveries of sediment digests were evaluated with NIST 2709a San Joaquin soils (hereinafter referred to as "SRM sample 2709a") and NIST 2711a Montana soil II (hereinafter referred to as "SRM sample 2711a"). Mean recoveries in SRM 2709a ranged from 48.4 to 87.1 percent of the certified concentrations (Boughton and others, 2020). The mean recoveries were within 25.5 percent of the 95 -percent confidence interval for copper, iron, manganese, nickel, and zinc. Elements with low certified concentrations (cadmium, 0.371 microgram per gram) or with a strong association with crystalline lattices (arsenic, chromium, lead) had lower percentage recoveries (between 37.9 and 50.4 percent). Mean recoveries in SRM 2711a ranged from 46.6 to 95.8 percent (Boughton and others, 2020). The percentage recoveries were within 17 percent of the 95-percent confidence interval for arsenic, cadmium, copper, iron, lead, nickel, and zinc and 22.8 percent for manganese. Chromium had the lowest mean recovery ( 46.6 percent), because of the strong binding nature of the crystalline lattice. No adjustments were made to trace-element concentrations in bed-sediment samples based on recovery efficiencies. Procedural blanks for bed-sediment samples consisted of the analysis of the same reagents used for sample digestion and reconstitution. Concentrated nitric acid used for sample digestion was heated and evaporated to dryness. After evaporation, $0.6 \mathrm{~N}$ hydrochloric acid was added to reconstitute the dry residue. Analytical results of procedural blanks for bed sediment (Boughton and others, 2020) were reported as a liquid-phase concentration, in micrograms per milliliter. A procedural blank was prepared and analyzed concurrently with bed-sediment samples for each site. Concentrations of trace elements in all procedural blanks were less than the MRL for all elements. No adjustments were made to analytical data based on procedural blanks.

\section{Tissue Concentrations}

Tissue data for the long-term monitoring program in the Clark Fork Basin consist of trace-element concentrations in the whole-body tissue of aquatic benthic invertebrates. Invertebrate samples were collected once annually at the same 13 sites and on the same dates as bed-sediment samples (fig. 1; table 1), 10 of which have USGS streamgages, allowing for a direct comparison of biological data with bed-sediment data and water-quality data. Biological data for water year 2018 are available in a machine-readable USGS data release (Boughton and others, 2020). Biological data for prior years are available by request in Microsoft Excel format from the authors. Warm Springs Creek at Warm Springs is sampled once every 3 years and was not sampled during water year 2018. Warm Springs Creek at Warm Springs was last sampled during water year 2017.

\section{Methods}

Insect samples were collected using protocols described in Hornberger and others (1997). Benthic insects at immature stages were collected with a large nylon-mesh kick net. A single riffle at each site was sampled repeatedly until an adequate number of individual insects was collected to provide enough mass for analysis (for example, about 10 stoneflies, about 100-200 caddisflies). Two caddisfly species of the genus Hydropsyche (Hydropsyche cockerelli and Hydropsyche occidentalis) were targeted for collection in this study because of their occurrence at most sites. Hydropsyche species (spp.) that could not be positively identified were categorized as Hydropsyche spp. or Hydropsyche morosa group. On the few occasions when Hydropsyche were not present, other caddisflies, including Brachycentrus spp. and Rhyacophila spp., were collected. The caddisfly Arctopsyche grandis and the stoneflies Claassenia sabulosa and Hesperoperla spp. were collected where available to represent additional insect taxa commonly distributed in the Clark Fork Basin but with different feeding traits.

Samples of each taxon were sorted by genus in the field and placed in acid-washed plastic containers. Samples were frozen in a small amount of ambient stream water on dry ice within 30 minutes of collection. Between 1986 and 1998, macroinvertebrate containers were kept on ice to allow the insects to evacuate their gut contents (depurate) for 6 to 8 hours. Excess water was drained, and insects were frozen for transport to the laboratory. Since 1999, samples were immediately frozen on dry ice in the field to reduce the possibility of metal loss through intracellular breakdown during depuration. A comparison of immediately frozen to depurated samples indicated that although no substantial difference occurred for most metals, concentrations of copper were about 20 percent lower in the depurated samples than in the samples that were immediately frozen. The data were not adjusted for this difference.

Invertebrate samples were processed and analyzed at the USGS ESPD Ecology and Contaminants Project Laboratory in Menlo Park, Calif. Insects were thawed and rinsed with ultrapure deionized water to remove particulate matter and then sorted to their lowest possible taxonomic level. If large numbers of specimens were collected at a site, similar-sized individuals were composited into replicate subsamples. Subsamples were placed in tared scintillation vials and oven dried at $70{ }^{\circ} \mathrm{C}$. Subsamples were weighed to obtain a final dry weight and digested by reflux using concentrated nitric acid (Cain and others, 1992). After digestion, insect samples were evaporated to dryness on a hot plate. The dry residue was reconstituted in $0.6 \mathrm{~N}$ hydrochloric acid, filtered through a $0.45-\mu \mathrm{m}$ pore-size filter, and analyzed undiluted using inductively coupled plasma-optical emission spectrometry (Hornberger and others, 1997) for arsenic, cadmium, chromium, copper, iron, lead, manganese, nickel, and zinc. The smallest concentration of a constituent that can be reliably reported for analyses of tissue samples is termed the MRL. 


\section{Results}

Concentrations of trace elements in whole-body tissue of aquatic invertebrates collected during August 2018 are listed in the accompanying data release (Boughton and others, 2020). The variability in the number of composite samples among species and among sites reflects differences in invertebrate abundance (the number of composite samples increases with the relative abundance of insects). Liquid-phase concentrations, in micrograms per milliliter, analyzed in the reconstituted samples were converted to solid-phase concentrations, in micrograms per gram, using equation 4 (used earlier in this report to calculate solid-phase concentrations of trace elements in bed sediment). All tissue samples were analyzed undiluted (the dilution ratio was 1 to 1). As with MRLs for trace elements in bed sediment, MRLs for trace elements in insects may differ among sites because of varied sample weights. In general, the smaller the sample weight (primarily a function of insect abundance), the higher the MRL; therefore, higher MRLs do not necessarily imply a higher trace-element concentration in tissue.

\section{Quality Assurance}

The USGS protocols for field collection and processing of tissue samples were designed to prevent contamination from metal sources. Nonmetallic nets, sampling equipment, and processing equipment were used in all sample collection. Equipment was acid washed and rinsed in ultrapure deionized water before the first sample collection. Nets and equipment were thoroughly rinsed in stream water at each main-stem site. Clean nets were used at each tributary site. Tissue samples were collected sequentially at sites along an increasing concentration gradient, which was from downstream sites to upstream sites, to minimize effects from potential site-to-site carryover contamination (Hornberger and others, 1997).

Quality control of analytical results for tissue samples included laboratory-instrument calibration with standard solutions and analyses of quality-control samples designed to quantify precision and to identify the presence and magnitude of bias. Quality-control samples consisted of 12 replicates of the certified reference material (CRM) TORT-3 (lobster hepatopancreas) purchased from the National Research Council Canada. Quality-control samples were analyzed in a proportion equivalent to about 20 percent of the total number of biota samples. Recovery efficiencies for trace-element analyses of the TORT-3 CRM are listed in the accompanying data release (Boughton and others, 2020). Data-quality objectives have not been established for analytical recovery in tissue, but percentage recoveries indicate analytical performance.
Mean CRM recoveries for TORT-3 ranged from 85.8 to 110 percent for all constituents except lead. The mean recoveries were within 15 percent (based on the 95-percent confidence interval) for arsenic, cadmium, chromium, copper, iron, manganese, nickel, and zinc. The high percentage recovery for lead (295 percent) might have occurred because of the relatively low certified concentrations in the standard. No adjustments were made to trace-element concentrations in biota samples based on recovery efficiencies.

Procedural blanks for biota consisted of undiluted aliquots of the same reagents used to digest and reconstitute tissue of aquatic insects. Analytical results of procedural blanks for biota (Boughton and others, 2020) were reported as a liquid-phase concentration, in micrograms per milliliter. A procedural blank was prepared and analyzed concurrently with tissue samples for each site. Concentrations of trace elements in all procedural blanks were less than the MRL; therefore, no adjustments to the data were necessary.

\section{Statistical Summaries of Data}

Statistical summaries of long-term water-quality, bed-sediment, and biological data for the Clark Fork Basin are provided in an accompanying USGS data release (Boughton and others, 2020) for the period of record at each site. The summaries include the period of record; number of samples; and maximum, minimum, mean, and median concentrations.

The summaries do not include data for supplemental samples collected at selected sites that targeted high-flow conditions or maintenance drawdowns of Milltown Reservoir, which might disproportionately skew the long-term statistics relative to the other sites in the network. Sample results at sites that have been sampled for other projects can be accessed in the NWIS database at https://waterdata.usgs.gov/mt/nwis/qw. Statistical summaries of long-term bed-sediment and biological data are based on results of samples collected once each year during the indicated years (Boughton and others, 2020). Because not all sites were sampled for bed sediment and biota every year, the data for some sites do not represent a consecutive annual record. Statistical summaries are not presented for discontinued sites.

Statistics for long-term bed-sediment data (Boughton and others, 2020) were based on the mean trace-element concentrations determined for each year from the mean of the analyses of composite samples; therefore, the number of samples for bed sediment represents the number of years that the constituent was analyzed. The number of arsenic samples for bed sediment was smaller than the number for other trace elements because sampling for arsenic began in September 2003. In addition, the number of samples analyzed for silver in bed sediment is smaller because analysis for this constituent was discontinued in 2004. 
In contrast, statistics for long-term tissue data (Boughton and others, 2020) were based on individual analyses for each composite sample collected rather than on a single mean concentration for each year. Differences in the number of composited invertebrate samples among species reflected differences in species abundance within and between sites and among years. As a result, the statistics for insects described a wider range of variation in trace-element concentrations than would be evident if results from individual composite samples were averaged. Also, the number of samples for arsenic in insect samples is smaller than the number for other trace elements because sampling for arsenic began in September 2003. The abundance of aquatic invertebrates at a site in a given year limits the biomass of the sample, which in turn, may result in varied MRLs. When MRLs vary among years, differences in concentration with time are difficult to determine, especially when a large percentage of the samples have concentrations less than MRLs.

The presence or absence of insect species at a given site can vary among years and may result in different taxa being analyzed in the long-term period of record. Because Hydropsyche insects were not sorted to the species level during 1986-89, statistics for sites sampled during those years were based on the results of all Hydropsyche species combined. At some sites, statistics for the Hydropsyche morosa group were based on the combined results for two or more species because these samples could not clearly be identified to the species level, but the individual insects had morosa characteristics.

\section{References Cited}

American Public Health Association, 1998, Standard methods for the examination of water and wastewater (20th ed.): Washington, D.C., American Public Health Association, American Water Works Association, and Water Environment Federation, 1,325 p.

Anderson, C.W., 2005, Turbidity (ver. 2.1): U.S. Geological Survey Techniques of Water-Resources Investigations, book 9, chap. A6, sec. 6.7, 64 p. [Also available at https://doi.org/10.3133/twri09A6.7.]

Andrews, E.D., 1987, Longitudinal dispersion of trace metals in the Clark Fork River, Montana, in Averett, R.C., and McKnight, D.M., eds., Chemical quality of water and the hydrologic cycle: Chelsea, Mich., Lewis Publishers, p. 179-191.

Axtmann, E.V., Cain, D.J., and Luoma, S.N., 1997, Effect of tributary inflows on the distribution of trace metals in fine-grained sediment and benthic insects of the Clark Fork River, Montana: Environmental Science \& Technology, v. 31, no. 3, p. 750-758. [Also available at https://doi.org/ 10.1021/es960417y.]

Axtmann, E.V., and Luoma, S.N., 1991, Large scale distribution of metal contamination in the fine-grained sediment of the Clark Fork River, Montana: Applied Geochemistry, v. 6, no. 1, p. 75-88. [Also available at https://doi.org/10.1016/0883-2927(91)90064-V.] 
Boughton, G.K., Hornberger, M.I., Turner, M.A., and Clark, G.D., 2020, Water-quality, bed-sediment, and invertebrate tissue trace element concentrations for tributaries in the Clark Fork Basin, Montana, October 2017September 2018: U.S. Geological Survey data release, https://doi.org/10.5066/P98IRLJF.

Brenton, R.W., and Arnett, T.L., 1993, Methods of analysis by the U.S. Geological Survey National Water Quality Laboratory-Determination of dissolved organic carbon by UV-promoted persulfate oxidation and infrared spectrometry: U.S. Geological Survey Open-File Report 92-480, 12 p. [Also available at https://doi.org/ 10.3133/ofr92480.]

Cain, D.J., Luoma, S.N., and Axtmann, E.V., 1995, Influence of gut content in immature aquatic insects on assessments of environmental metal contamination: Canadian Journal of Fisheries and Aquatic Sciences, v. 52, no. 12, p. 2736-2746. [Also available at https://doi.org/10.1139/f95-862.]

Cain, D.J., Luoma, S.N., Carter, J.L., and Fend, S.V., 1992, Aquatic insects as bioindicators of trace element contamination in cobble-bottom rivers and streams: Canadian Journal of Fisheries and Aquatic Sciences, v. 49, no. 10, p. 2141-2154. [Also available at https://doi.org/ 10.1139/f92-237.]

Cannon, M.R., and Johnson, D.R., 2004, Estimated water use in Montana in 2000: U.S. Geological Survey Scientific Investigations Report 2004-5223, 61 p. [Also available at https://doi.org/10.3133/sir20045223.]

Cleasby, T.E., Hornberger, M.I., Heinert, T.L., and Turner, M.A., 2019, Water-quality, bed-sediment, and biological data (October 2016 through September 2017) and statistical summaries of data for streams in the Clark Fork Basin, Montana: U.S. Geological Survey Open-File Report 2019-1060, 110 p., accessed November 2019 at https://doi.org/10.3133/ofr20191060.

Davis, B.E., and the Federal Interagency Sedimentation Project, 2005, A guide to the proper selection and use of federally approved sediment and water-quality samplers: U.S. Geological Survey Open-File Report 2005-1087, 20 p. [Also available at https://doi.org/10.3133/ofr20051087.]

Dodge, K.A., and Lambing, J.H., 2006, Quality-assurance plan for the analysis of suspended sediment by the U.S. Geological Survey in Montana: U.S. Geological Survey Open-File Report 2006-1242, 25 p. [Also available at https://doi.org/10.3133/ofr20061242.]

Driscoll, A., and Hatcher, J., 2010, Chain of custody: U.S. Geological Survey National Water Quality Laboratory, SOP QUAX0030.4, effective May 5, 2010, 17 p. [Also available at http://wwwnwql.cr.usgs.gov/USGS/htmls/ QUAX0030.4controlled.pdf.]
Edwards, T.K., and Glysson, G.D., 1999, Field methods for measurement of fluvial sediment: U.S. Geological Survey Techniques of Water-Resources Investigations, book 3, chap. C2, 89 p. [Also available at https://doi.org/10.3133/ twri03C2.]

Fishman, M.J., ed., 1993, v. 93-125. Methods of analysis by the U.S. Geological Survey National Water Quality Laboratory-Determination of inorganic and organic constituents in water and fluvial sediments, U.S. Geological Survey Open-File Report, 217 p. [Also available at https://doi.org/10.3133/ofr93125.]

Fishman, M.J., and Friedman, L.C., 1989, Methods for determination of inorganic substances in water and fluvial sediments: U.S. Geological Survey Techniques of Water-Resources Investigations, book 5, chap. A1, 545 p. [Also available at https://doi.org/10.3133/twri05A1.]

Friedman, L.C., and Erdmann, D.E., 1982, Quality assurance practices for the chemical and biological analyses of water and fluvial sediments: U.S. Geological Survey Techniques of Water-Resources Investigations, book 5, chap. A6, 181 p. [Also available at https://pubs.usgs.gov/twri/twri5a6/.]

Garbarino, J.R., Kanagy, L.K., and Cree, M.E., 2006, Determination of elements in natural-water, biota, sediment, and soil samples using collision/reaction cell inductively coupled plasma-mass spectrometry: U.S. Geological Survey Techniques and Methods, book 5, chap. B1, 88 p. [Also available at https://doi.org/10.3133/tm5B1.]

Garbarino, J.R., and Struzeski, T.M., 1998, Methods of analysis by the U.S. Geological Survey National Water Quality Laboratory-Determination of elements in whole-water digests using inductively coupled plasma-optical emission spectrometry and inductively coupled plasma-mass spectrometry: U.S. Geological Survey Open-File Report 98-165, 101 p. [Also available at https://doi.org/10.3133/ofr98165.]

Guy, H.P., 1969, Laboratory theory and methods for sediment analysis: U.S. Geological Survey Techniques of Water-Resources Investigations, book 5, chap. C1, 58 p. [Also available at https://doi.org/10.3133/twri05C1.]

Hoffman, G.L., Fishman, M.J., and Garbarino, J.R., 1996, Methods of analysis by the U.S. Geological Survey National Water Quality Laboratory-In-bottle acid digestion of whole-water samples: U.S. Geological Survey Open-File Report 96-225, 28 p. [Also available at https://doi.org/ 10.3133/ofr96225.]

Hornberger, M.I., Lambing, J.H., Luoma, S.N., and Axtmann, E.V., 1997, Spatial and temporal trends of trace metals in surface water, bed sediment, and biota of the upper Clark Fork Basin, Montana, 1985-95: U.S. Geological Survey Open-File Report 97-669, 84 p. [Also available at https://doi.org/10.3133/ofr97669.] 
Horowitz, A.J., Demas, C.R., Fitzgerald, K.K., Miller, T.L., and Rickert, D.A., 1994, U.S. Geological Survey protocol for the collection and processing of surface-water samples for the subsequent determination of inorganic constituents in filtered water: U.S. Geological Survey Open-File Report 94-539, 57 p. [Also available at https://doi.org/ 10.3133/ofr94539.]

Jones, B.E., 1987, Quality control manual of the U.S. Geological Survey's National Water Quality Laboratory: U.S. Geological Survey Open-File Report 87-457, 17 p. [Also available at https://doi.org/ 10.3133/ofr87457.]

Lambing, J.H., comp., 2006, Quality-assurance plan for water-quality activities of the U.S. Geological Survey Montana Water Science Center: U.S. Geological Survey Open-File Report 2006-1275, 39 p. [Also available at https://doi.org/10.3133/ofr20061275.]

Luoma, S.N., and Bryan, G.W., 1981, A statistical assessment of the form of trace metals in oxidized estuarine sediments employing chemical extractants: The Science of the Total Environment, v. 17, no. 2, p. 165-196. [Also available at https://doi.org/10.1016/0048-9697(81)90182-0.]

Patton, C.J., and Kryskalla, J.R., 2011, Colorimetric determination of nitrate plus nitrite in water by enzymatic reduction, automated discrete analyzer methods: U.S. Geological Survey Techniques and Methods, book 5, chap. B8, 34 p. [Also available at https://doi.org/10.3133/ tm5B8.]
Pritt, J.W., and Raese, J.W., eds., 1995, v. 95-443. Quality assurance/quality control manual-National Water Quality Laboratory: U.S. Geological Survey Open-File Report, 35 p. [Also available at https://doi.org/10.3133/ofr95443.]

Rantz, S.E., and others, 1982, Measurement and computation of streamflow: U.S. Geological Survey Water-Supply Paper 2175, v. 2, 631 p., accessed November 2019 at https://doi.org/10.3133/wsp2175.

Taylor, J.K., 1987, Quality assurance of chemical measurements: Chelsea, Mich., Lewis Publishers, 328 p.

U.S. Geological Survey, 2020, USGS water data for the Nation: U.S. Geological Survey National Water Information System database, accessed January 2020 at https://doi.org/ 10.5066/F7P55KJN.

U.S. Geological Survey, variously dated, National field manual for the collection of water-quality data: U.S. Geological Survey Techniques of Water-Resources Investigations, book 9, chaps. A1-A10, accessed November 2019 at https://water.usgs.gov/owq/FieldManual/.

Wagner, R.J., Boulger, R.W., Jr., Oblinger, C.J., and Smith, B.A., 2006, Guidelines and standard procedures for continuous water-quality monitors-Station operation, record computation, and data reporting: U.S. Geological Survey Techniques and Methods, book 1, chap. D3, 51 p., 8 attachments. [Also available at https://doi.org/10.3133/ tm1D3.]

Ward, J.R., and Harr, C.A., eds., 1990, v. 90-140. Methods for collection and processing of surface-water and bed-material samples for physical and chemical analyses, U.S. Geological Survey Open-File Report, 71 p. [Also available at https://doi.org/10.3133/ofr90140.] 
For more information about this publication, contact:

Director, USGS Wyoming-Montana Water Science Center 3162 Boseman Avenue

Helena, MT 59601

406-457-5900

For additional information, visit:

https://www.usgs.gov/centers/wy-mt-water/

Publishing support provided by the U.S. Geological Survey Science

Publishing Network, Rolla and Sacramento Publishing Service Centers 
